\title{
The Radical Traditionalist: NaOmi Mitchison, Aud THE DEEP-MINDED AND THE LAND THE RAVENS FOUND
}

\author{
Cori L. Gabbard*
}

As one of the works that the Scottish writer Naomi Mitchison (1897-1999) wrote during the second of "two very distinct periods"- "1924-37" and "1952-57"-when she based her narratives upon medieval Scandinavian ones, ${ }^{1}$ The Land the Ravens Found (1955) reflects the accumulation of its writer's knowledge concerning Norse culture, a subject that had piqued her interest since childhood when, according to her memoirs, she first read a few of the Icelandic sagas. ${ }^{2}$ In 1924, Jonathan Cape Limited published Mitchison's When the Bough Breaks whose title story features a Norse protagonist. Five years later, Mitchison spent much of the spring of 1929 in Oslo's museums for the purpose of examining Norse sea vessels; ${ }^{3}$ what she learned from these visits informed, among other works, the composition of The Swan's Road ${ }^{4}$ her historical account of the Vikings' conquests throughout the world which the Naldrett Press published in 1954.

As noted by Julian Meldon D'Arcy, whose chapter on Mitchison in his Scottish Skalds and Sagamen comprises the only other analysis (besides this current essay) of The Land the Ravens Found, Mitchison's bibliography for The Swan's Road is indicative of her extensive immersion in Norse history and literature in the decade following the Second World War when more-or-less annual visits to her friend Sonja Carstensen Meyer in Denmark resulted in

* Cori L. Gabbard earned her doctorate in English literature from The Graduate Center of the City University of New York. A specialist in medieval and post-1900 British literature, she is currently revising her dissertation into a book manuscript and teaches works by Naomi Mitchison, Ian Hamilton Finlay, Maud Sulter, Irfan Merchant, Kokumo Rocks and Carol Ann Duffy (among others) at the New York City College of Technology. 
a re-acquaintance with-and a greater appreciation for-the Icelandic sagas. ${ }^{5}$ Mitchison consulted with scholars in the disciplines of history and archaeology; not surprisingly, her sources for The Swan's Road include several works in these respective fields, such as the second, third and fourth volumes of the Cambridge Mediaeval History; Saxo Grammaticus' Danish History (c.late twelfth/early thirteenth century); Fridtjof Nansen's In Northern Mists: Arctic Exploration in Early Times (1911); T. D. Kendrick's History of the Vikings (1930); Thomas Charles Lethbridge's Herdsmen \& Hermits: Celtic Seafarers in the Northern Seas (1950); James Ritchie's The Influence of Man on Animal Life in Scotland (1920); Haakon Shetelig and Hjalmar Falk's Scandinavian Archaeology (1937); and V. Gordon Childe's Scotland Before the Scots: Being the Rhind Lectures for 1944 (1946). ${ }^{6}$ In addition, Mitchison acknowledged the debt she owed to Heimskringla saga (History of the Kings of Norway), Orkneyinga saga (The History of the Earls of Orkney), Brennu-Njáls saga (The Saga of Burnt Njal) and Fareyinga Saga (Saga of the Faroe Islanders $).{ }^{7}$ She apparently did not read these texts in their original Icelandic, as her praise for Sir George Webbe Dasent's English translations of Orkneyinga saga and Brennu-Njáls saga implies, ${ }^{8}$ although she did visit Copenhagen's Royal Library to look at the Norse manuscripts in its collection. ${ }^{9}$

The bibliography for The Swan's Road also cites Gudbrand Vigfusson and F. York Powell's Origines Islandicae: A Collection of the More Important Sagas and Other Native Writings Relating to the Settlement and History of Early Iceland (1905) as its source for a number of its chapters. One of the texts for which Vigfusson and Powell provide an edition and a corresponding translation is Landnámabók (The Book of Settlements), which is, ostensibly, a record of those who claimed land in Iceland during its Settlement Period (870-930). ${ }^{10}$ The sixth chapter of The Swan's Road, which Mitchison entitled "The Land the Ravens Found," alludes to and quotes from Origines Islandicae's translation of Landnámabók extensively. Significantly, "The Land the Ravens Found" summarizes and quotes from Landnámabók's account of the Icelandic settlement of a woman named Aud the Deep-Minded (Auðr in djúpúðga), as well as from Laxdcela saga's version of the 
same story as Vigfusson and Powell have translated it in Origines Islandicae. $^{11}$

Mitchison's postscript to The Land the Ravens Found, which states that "THE SKELETON of this story comes from the Landnamabok [sic]" and that its "translation, called Origines Icelandicae [sic], can be got out of [one's] City or County Library," 12 identifies the narrative source of her own novel and explicitly positions her work as an expansion upon Landnámabók while implicitly situating it as an extension of The Swan's Road, which is also informed by the knowledge she gained from her 1929 stay in Oslo. ${ }^{13}$ With the exception of the fact that the Norse text locates the matriarch first in Dublin and then in the Hebrides before placing her in Caithness while the novel initially situates her in the latter, The Land the Ravens Found more-or-less follows and expands upon the chronology of events that Aud's settlement narrative comprises. More to the point, the post-1945 novel, like the medieval text, inscribes its protagonist with thematic consistency through its evocation of these incidents. Landnámabók identifies Aud as the only woman among Iceland's "best-born settlers" (pesser land-náms-menn hafa gaofgaster vereð) ${ }^{14}$ a status that defines her in terms of masculinity even as the text's overall description of her and her land-taking (landnám) represents a blurring of gender boundaries. ${ }^{15}$ Indeed, the etymological, legal, grammatical and narrative implications of Landnámabók's description of Aud's land-taking intensify its masculinization of her, not only by calling attention to the ways in which her settlement resembles those of her peers but also by identifying her with war, which, in terms of who participated in actual combat, was wholly a male domain within medieval Scandinavia.

Insofar as any one episode comprised by Aud's land-taking exemplifies the distinction between Landnámabók's depiction of her and Mitchison's depiction, this essay will comparatively examine the events that constitute her actual settlement in both texts in order to define the nature of her thematic import in Mitchison's novel relative to what she embodies in Landnámabók. The implications of this comparison, as I shall demonstrate, complicate our understanding of Mitchison as a twentieth-century writer and, through her work, interrogate the binary opposition of 
the terms "medieval" and "modern" as we commonly perceive them in relation to one another, which is to say that we associate the former with backwardness and irrelevance while connecting the latter term with innovation and progression. Disagreement as to how we should categorize Mitchison in terms of genre notwithstanding, ${ }^{16}$ there is no question that her writing from the very first has served as a conduit for her political views and concerns about contemporary politics. ${ }^{17}$ The Land the Ravens Found is no exception to this paradigm. Relative to "her Norse fiction from the 1920s and 30s," the 1955 novel "marks a new optimism in [her] view of the future of racial relations": if "[i]n the pre-war short stories her Norse characters could not ultimately extend their loyalty beyond tribal or racial limits," The Land the Ravens Found demonstrates that "differences in race, religion and language can be assimilated to form a new sense of identity, unity and pride." ${ }^{\prime 18}$ More pertinently to the argument I shall put forth here, the book was the outcome of both the author's personal convictions and her post-war activism. Affirming her long-held pacifism, Mitchison at some point after 1950 but before 1955 became "vice-chair" of the newly formed Authors' World Peace Appeal (AWPA) which represented the concerns of numerous writers, the majority of whom were British, about "the threat of war posed by the tension between the United States and the Soviet Union." 19 That organization desired "to create an alternative children's literature to the comics and books featuring war and violence which US troops had brought into Britain when they were stationed there during the [Second World] [W]ar." ${ }^{20}$ Mitchison's response to this ambition was twofold. First, she wrote "The Writer and the Child" which The New Statesman and Nation published in its February 12, 1955 issue. ${ }^{21}$ In this essay, Mitchison argues that "a certain amount of violence, both in life and literature, is necessary for the happiness of normal children, but that it can be a violence unrelated either to cruelty or war", 22 and that

$[\mathrm{w}]$ hen writing for children we have no right to oversimplify moral issues ... we must not leave out love; and we should not leave out hate ... If we see the blow, we must also feel the pain and see the corpse, and know the result both on killed and killer ... We 
have a duty to present alternatives to war which will make peace just as exciting and dangerous and full of generous situations. ${ }^{23}$

Second, Mitchison produced The Land the Ravens Found. ${ }^{24}$ This work, which Collins released in the same year that The New Statesman and Nation published "The Writer and the Child," certainly lives up to its author's claims on behalf of her own treatment of conflict in her own narratives written for children: "What I have tried to do in my own books for children is to make violence and warfare real and to explain what is really happening to people: that is, to show the historical consequences of actions-or, in other words, the moral. ${ }^{.25}$

Given this context, it therefore is no surprise that in The Land the Ravens Found, Mitchison's protagonist channels her pacifism. Yet the matriarch's embodiment of peace in this work is inextricable from Mitchison's overall presentation of her, a portrayal that somewhat contradicts the radical feminism that informed all aspects of Mitchison's life, including her writing, and that was an integral aspect of her progressive politics. By the end of 1930, Mitchison was the mother of six children, ${ }^{26}$ the most recent of whom was born in the fourteenth year of what overall would be a happy marriage of fifty-four years ${ }^{27}$ that, five years earlier, had evolved into an open relationship, the author and her spouse having both taken lovers independently of each other. At the start of 1931, Mitchison was also the published author of two novels, a volume of poetry, several collections of short stories, a biography and an essay, "Comments on Birth Control" (1930), in which she asserts that marriage is no more than "domestic prostitution" 28 when wives have no financial independence apart from their spouses and resign themselves to a lifetime of mediocre sex "in exchange for economic security, ${ }^{29}$ claiming that within some contexts, extramarital affairs might enhance the respective relationships between the members of all involved parties. ${ }^{30}$ Indeed, Mitchison viewed such relationships as integral to that which she defines as the ideal for women like her: 
Intelligent and truly feminist women want two things: they want to live as women, to have masses of children by the men they love and leisure to be tender and aware of both lovers and children; and they want to do their own work, whatever it might be ... They insist-as I think they should-on having both worlds, not specializing like bees or machines ${ }^{31}$

As Mitchison's life and comments make clear, it was as a feminist that she felt contempt for, and actively rebelled against, the conventionalities of a womanhood that was defined by and limited to the domestic sphere, particularly in the form of monogamous subservience to a spouse who supported her financially. It is my argument here that in constructing Aud as the embodiment of her anti-war sentiments in The Land the Ravens Found and thus mitigating Landnámabók's association of her with war, Mitchison - by default given the actualities of medieval Iceland's social structure-defines her protagonist in terms of traditional gender roles and boundaries such that she, in contrast to her medieval counterpart, is a comparatively de-radicalized figure.

\section{Aud in the Hauksbók $k^{32}$ text of Landnámabók}

In its entirety, Landnámabók exists in two manuscripts, Sturla Pórðarson's Sturlubók $(1275 \times 80)$ and Haukr Erlendsson's Hauksbók (1306x08). Vigfusson and Powell based their edition and translation of Landnámabók upon Hauksbók. For this reason, my analysis of Landnámabók here, which will demonstrate how the text identifies Aud with masculinity and war from a narrative, etymological, grammatical and legal perspective, reflects my reading of Vigfusson and Powell's edition and translation of Hauksbók despite the fact that Sturlubók is the source text for the standard, scholarly editions of Landnámabók: Jakob Benediktsson's Icelandic edition (Landnámabók in Íslendingabók: Landnámabók, Íslenzk fornit, Bd. 1, ed. Jakob Benediktsson [Reykjavík: Hið Íslenzka Fornritafélag, 1968], 31-397) and Hermann Pálsson's and Paul Edwards' English translation (eds. Haraldur Bessason and Robert J. Glendinning [Winnipeg: University of Manitoba, 1972]). 
Landnámabók relates that Aud temporarily stays with one of her brothers, Helgi Biolan, before lodging with her other brother, Beorn, in Broad-frith, for the duration of her first winter in Iceland. Then "in the spring," she "and her company [go] into Broad-frith to explore the land" (78): ${ }^{33}$

They took their day meal at a place north [so S, but MS. south] of Broad-frith, which is now called Daymeal-ness. Afterwards they went inland through the island channels, and landed at the ness, where also Aud lost her comb, and this ness she called Combness. $(78)^{34}$

Margaret Clunies Ross singles out these details in order to point out how they distinguish Aud's landnám from those of the male settlers (landnámsmenn):

[n]o supernatural events are recorded in connection with her land-taking activities. Instead, the placenames that celebrate various of her acts as she moves about exploring the territory are mundane, domestic, or personal in their scope. ${ }^{35}$

Nevertheless, Clunies Ross' own remarks inadvertently and indirectly point to the ways in which Aud's journey from Broadfrith underscores similarities between her landnám and that of her acknowledged peers. Clunies Ross notes, as the passage above implies, that Day-meal-ness acquires its name from the fact that it is where Aud "and her companions [eat] their first breakfast while looking for land" ${ }^{36}$ and that she gives Comb-ness its name because that is where she "[loses] her comb.", This phenomenon of naming places in commemoration of the settlers' experiences in them is a feature not only of Aud's landnám but also of the land-takings of three of her equals, one of whom is Scald-Grim. With respect to his settlement, the naming occurs, as it does with Aud's, when its protagonist is surveying the landscape of his new country, still yet to come across the soil that he will stake as his own: 
Scald-Grim came ashore at the place that is now called Cog-ness in the Mire or Fen. Afterwards he explored the land, and there was a great fen-land and broad shaws, far between fell and foreshore, and when they ${ }^{38}$ journeyed inward along the frith they came on a ness where they found wild swans, wherefore they called it Elfets-ness [Wild-swans's-ness]. $(38)^{39}$

Cetil-beorn the Old is another peer of Aud's; his settlement, like hers and like Scald-Grim's, also involves the phenomenon of naming topographical features; and it parallels Aud's in other ways as well. Like Aud, Cetil-beorn lives with a relative (in his case, his wife's father, Thord Beardie) when he initially comes to Iceland, and it is at the end of winter, when he is searching for suitable land to claim, that he encounters the two natural resources that he names. Notably, the name of the stream in which Cetil-Beorn loses his axe and that of the crag in which he subsequently forgets his trout allude to these losses just as "Comb-ness" alludes to the loss of Aud's comb:

they ${ }^{40}$ came to a river, which they called the river Axe-water, because they lost their axe there. They took up their abode for a while under the mull of the hill, which they called Trout-mull, for there they left behind [forgetting them] the river-trout that they took out of the river. $(228)^{41}$

Ingimund the Old is the third of Aud's equals whose landnám encompasses the bestowal of a name upon a previously unnamed natural resource; he, too, does so before he has arrived at the site that he ultimately settles, and in the company of his followers, which in his case includes two friends, his wife's brother and five serfs. And like Aud and Cetil-beorn, Ingimund is a guest for the duration of his initial cold season in Iceland. More importantly, the wood that Ingimund enters acquires its name from what he discovers there: he and his party "[come] into a frith, where they [find] two rams, and [call] it therefore Ram-frith" (127). ${ }^{42}$ 
That the land-taking narratives of the other women settlers (landnámskonur) do not feature any such episodes heightens Landnámabók's identification of Aud with the other "best-born settlers," although a few of the other women who have claimed land in Iceland are the namesakes of specific places: Arnbjorg, of Arnbjargar Brook; Thorunn, of Thorunnrholt; Thorbjorg Pole, of Stangarholt; ${ }^{43}$ and Ljot, of Ljotarstead. But the fact that Aud, too, is a namesake (of Audartoft) does not define her landnám in terms of gender because it is a commonplace in Landnámabók for settlers of both genders to be namesakes of geographical features, as are some of the "best-born settlers" including Ingolf, of Ingolfsfell; Bjorn the Gold-Bearer, of Gullberastead; Hastein (Ha-stan) Atlesson, of Hasteins Sound; and Auðr's own brother, Bjorn (Beorn) the Easterner, of Bjarnarhaven.

The seemingly innocuous circumstances that result in the naming of Comb-ness also tie Aud to war, and do so, as I shall argue shortly, in a way that contextualizes her landnám as conquest. Norse wives typically obscured their hair, which they "gathered up into a knot at the back of the head" 44 under a veil. Norse combs, as we may deduce from Sturtevant's examination of "hor-," 45 had, at the very least, the same basic purpose that they have in the twenty-first century. In light of these facts, I would argue that we may interpret Aud's loss of her comb as an event that disassociates her not only from the civilizing norms that govern regulations of appearance, among other things, but also from those societal strictures that define normative gender roles. Combless, Aud's hair is both free and wild, a condition that imbues it with the militaristic "symbolism of unkempt hair." 46 Saxon gladiators perceived the Suebi as their adversaries, and one particular year in the late sixth century, six chiliads of the former took an oath "not to cut hair or beard until they avenged themselves" on the latter. ${ }^{47}$ Significantly, these fighters had a Norse counterpart in King Harold Hárfagri ("Fair-hair") whose moniker "was Harold Unkempt until he conquered all of Norway." 48 Given that Aud's vulnerability as the mother of Scotland's recently deposed king motivates her departure first to the Orkney Islands and then to Iceland, her hair ironically identifies her with the very monarch whose tyranny is the cause of so many future Icelanders' departure from Norway in both 
Landnámabók and the Íslendingasögur ("sagas of Icelanders"). ${ }^{49}$ That is, the woman's combless tresses identify her with warriors who have yet to achieve their first military victories, ${ }^{50}$ and I would argue that the narrative adjacency of her literal landnám to the loss of her comb - the former immediately follows the latter-posits the settlement itself as a metaphorical conquest, an interpretation that Landnámabók's own structural parallels and deployment of language support. With respect to the first, Scald-Grim, Cetil-beorn and Ingimund each claim land after naming the topographical features they respectively encounter, and Aud is no different. With respect to the second, it is worth noting that the Norse equivalent of "lost" that Landnámabók deploys is the third person, preterite singular of the infinitive tapa. The primary meaning of this word is, obviously, "to lose." 51 The secondary meaning of tapa, however, is "to destroy, kill."

Landnámabók's depiction of the actual moment of Aud's land-taking is superficially both anti-climatic and perfunctory in its adherence to formulae:

Aud took in settlement all the Dale-lands [here falls in the second blank in $H$; see Introduction], at the inward of the friths, from Day-meal-ness to Scramleap-water. She dwelt at Hvam, on the Trout-wateroyce, at a place called Aud's-tofts. (78-79) ${ }^{53}$

Yet the very mundanity of this depiction, which technically involves neither bloodshed nor conquest, is what paradoxically makes it interesting from an analytical perspective. The clause " $[\mathrm{X}]$ nam [Y]" (" $[\mathrm{X}]$ took possession of $[\mathrm{Y}]$ ") is the formulaic expression that Landnámabók (typically) uses to describe the actual moment of land-taking in an entry for a given settler. Auðr nam aoll Dala-laond i innan-verðom firðenom frá Daogorðar-ao til Skraumo-hlaups-ár obviously follows this paradigm. The landnám narratives of thirty-three of Aud's male cohorts contain some version of this clause, ${ }^{54}$ which is to say that the settlement accounts of approximately eighty-seven percent $t^{55}$ of the male "best-born settlers" not only deploy this syntactical construction but do so consistently in Hauksbók, and thirty-one of these thirty-three 
landnámsmenn are the single claimants of the land they take, the exceptions being Cetil Thidrandsson and his brother Grout-Atle who settle in Fleet-dale as joint claimants. ${ }^{56}$ By contrast, Hauksbók deploys the clause "[X] nam [Y]" in order to describe the landnám of only one other woman settler (landnámskona) besides Aud. That woman is As-gerd, and she is the only other woman whom the manuscript depicts unambiguously as a single claimant of previously unsettled land. In light of these statistics, Landnámabók's use of the clause "[X] nam [Y]" to describe the moment of Aud's actual settlement reinforces her place among the other "best-born settlers," while the denotative meaning of nema identifies her with conflict and Norse masculinity. The equation of nema with "to take" is "limited, for taka (q. v.) is the general word, whereas nema remains in special usages," by force, seize upon.,"58 Certainly, "[taking] by force" and "[seizing]" are actions that are intrinsic to war, and again, only men literally participated in battle during the Settlement Period.

But if much of my analysis here has emphasized the ways in which Landnámabók distinguishes Aud from the other landnámskonur by showing how she, or the details of her settlement, resemble the most prominent landnámsmenn, or the particulars of their land-takings, Hauksbók's depiction of Thorgerd's settlement calls attention to the way in which Aud does not perform as a woman insofar as her actual land-taking contrasts with the former's, although the text initially creates a limited parallel between the two women. Both are widows who have borne male offspring when they arrive in Iceland, and the work begins its account of Thor-gerd's settlement by introducing her husband, Asbeorn, in the same way that it commences its narrative of Aud's landnám by introducing her spouse Anlaf the White. But unlike Aud whose journey to Iceland is largely a reflection of her will and authority even if the death of her son Thor-stan the Red, and the potential harm she might now face in his absence, underlie her decision to abandon Scotland, Thor-gerd commences her voyage as the wife of a potential settler. She claims land when she sets foot in Iceland only because As-beorn dies before she gets to the island in the company of their two sons who obviously, unlike Thor-stan the Red, are alive. ${ }^{59}$ And that settlement, as Hauksbók explicitly states, 
conforms to the legal standards governing the acquisition of land by women: ${ }^{60}$

2. Now it was held law, that a woman should not take in settlement more land than a quhae or heifer of two years old could go round on a spring day from sunrise to sunset, a half-stalled neat, and well kept. Wherefore Thor-gerd led her heifer under Toft-fell a short way from Fold-River in the south, and into Kid-point, hard by Iockle's-fell on the west.

3. Then Thor-gerd took in settlement land over all Ing-wolf's-head-wharf, between Fold-river and Iockle-river, and dwelt at Sand-fell. (191) ${ }^{61}$

\section{Aud in The Land the Ravens Found}

Methodologically, my analysis of The Land the Ravens Found is based to a lesser extent upon my knowledge of Old Norse, which, as I mentioned previously, Mitchison did not share, and to a greater extent upon both my own close reading of this novel and scholarly research published mostly after 1955 . This fact does not, however, invalidate my conclusions in that most of what I specifically discuss with respect to the research I cite does not constitute knowledge that would have been non-existent before 1955 even if its sources did not come into print until long after the publication of The Land the Ravens Found. My citation of Patrick F. Wallace's "The Archaeology of Ireland's Viking-Age Towns" to substantiate that the Vikings viewed Ireland as a bullion reserve is a case in point. Wallace's essay appears in A New History of Ireland I: Prehistoric and Early Ireland, which has a copyright date of 2008. But in the first chapter of The Swan's Road, Mitchison refers to the plunder of Viking raids that took place in Ireland (and also in Scotland and England) between 700 and $899 .{ }^{62}$

Likewise, it is not difficult to imagine that Mitchison was familiar with the significance and details of certain traditions, values and ideas that have persisted in rural Scottish communities over centuries since the Vikings invaded them, knowledge to which scholarly criticism may or may not have referred before 1955 (the 
sources I cite here may not be the first to discuss some of the details that I specifically analyze in this essay). Mitchison's visits to Meyer after the Second World War also increased her consciousness of the extent to which Viking customs still persisted into twentieth-century Scotland, ones that she herself perpetuated through her experiences with farming and fishing. ${ }^{63}$ At Carradale in Kintyre, which became her permanent residence after the summer of 1939 owing to the start of the Second World War, Mitchison attempted to foster a sense of community in her Scottish village based upon her socialist principles, ${ }^{64}$ establishing friendships that transcended class boundaries. ${ }^{65}$ One of the ways in which she did so was to work on her own land alongside the working-class members of her community whom she had hired to perform such labour while another was to go fishing with those whose livelihood it was. ${ }^{66}$

In The Land the Ravens Found, Aud's land claim also takes place during the first spring she spends in Iceland, the details of which initially expand upon, but do not subvert, Landnámabók's first reference to Aud's landnám, as follows:

The winter came to an end at last and the young grass began to show green in the low-lying land ... Aud decided to go and take up her new lands.

She and Coll and Anlaf had their own horses, but she had borrowed others from Beorn for some of the men ... They started in the early dawn of a clear morning, riding off through Beorn's lands and beyond ... By mid-morning they were past any land which had been claimed, riding up a narrow marshy glen under birch and alder. (145-46) ${ }^{67}$

Yet Aud's landnám as The Land the Ravens Found depicts it undercuts Landnámabók's identification of her with her peers. First, the only settlement that The Land the Ravens Found depicts is Aud's, thereby stripping it of the comparative framing that the other settlement narratives in Landnámabók provide. Second, the novel portrays its heroine as a figure whose authority is inconsistently unilateral. Although it is Aud herself who, in keeping 
with her stated intentions, determines the timing of her settlement, the fact that "the men [take] it in turns to go ahead and find the best way" (146) because of the dangers posed by dead, fallen trees, snowdrifts and the absence of any sort of path is indicative of the extent to which she cedes control of the situation to others, and it is worth emphasizing that Gudbrand Vigfusson and F. York Powell's reference to Aud's entourage ${ }^{68}$ in their translation of Hauksbók renders explicit what is implicit in Haukr Erlendsson's manuscript: Aud is the only explicit, grammatical subject who ventures "into Broadfrith" according to Hauksbók, which by default posits her as an autonomous settler.

As in Landnámabók, Aud in Mitchison's novel resumes her expedition at the conclusion of her meal. Not surprisingly, The Land the Ravens Found continues to expand upon the medieval work's portrayal of this episode, which unlike the passage below tersely describes the topographical features of the area that Aud explores, explicitly relating her actions and those of her entourage while barely hinting at her mindset:

After dinner they went on and now Aud kept her eyes open for the best place to build her Hall, somewhere flat and fairly sheltered. The inland plateau was flat enough but the winter winds would skin it like a knife. And she must have a hot spring somewhere near for a bath-house! (147)

The passage above corresponds to Aud's movement "inland," detailing the qualities of the land that she encounters from her perspective. On the surface, Aud's specifications obviously reflect the pragmatic concerns that all settlers, whether men or women, would have considered between 870-930 when deciding where to claim land: ${ }^{69}$ in order to endure, her Hall should be in a location that will protect it from the effects of Iceland's climatic elements, and it must be in proximity to a "hot spring." But relative to Aud's exploration of Iceland's terrain as Landnámabók depicts it, her reasoning in the 1955 novel reinforces its identification of her with pacifism. Aud's rejection of " $[\mathrm{t}] \mathrm{he}$ inland plateau" as an appropriate site for her "Hall" because the "winter winds would skin it like a 
knife" implies that it should be devoid of all connotations of violence, even those that are domestic in nature. Although killing animals for food was the duty of men, ${ }^{70}$ women had responsibility for "processing and converting the results of male work for shortterm consumption and long-term preservation." Aud's further stipulation that she "have a hot spring somewhere near for a bath-house" reinforces not only her distance from war but also her connection to specifically female roles within medieval Icelandic society. First, the "bath-house" was the one place where men disarmed themselves. ${ }^{72}$ But second, women did all of the laundry, a chore they routinely combined with taking a bath during their own trips to the "[h]ot springs." 73

Just as The Land the Ravens Found imparts psychological complexity to its depiction of Aud's search for land, it also imbues that experience with causal connection. Landnámabók provides no particular reason as to how or why Aud "[loses] her comb"; the novel implies that its loss is owing to the fact that it is "difficult going especially when they [come] to places where there [are] great rocks scattered," as follows:

It was a beautiful gold and ivory comb that held her hair together at the back; when they halted and got their breath after a scramble it was gone. Aud was really upset and sent back all the men to look for it, but try as they might it was nowhere to be seen. However by the time they had all hunted and finally given it up, she had decided there were more things to worry about than that; they must go on, but this headland where she was sitting waiting for them would be Combness. (147-148)

In both Landnámabók and The Land the Ravens Found, Aud sails from Caithness for Iceland (by way of the Orkney Islands) in the company of her grandchildren, among others, after Scotland's conqueror-her son, Thorstan-dies in conflict. Thus although navigating Iceland's terrain is problematic for Aud as well as for those accompanying her, her comparative lack of youth superficially explains her need to have those in her entourage search for her comb. Yet this necessity simultaneously emphasizes her comparative inability to manoeuver through Iceland relative to 
that of her men, and the importance of this difference lies in its affirmation of the division between the domains of war and civilian life that the opening paragraph of The Land the Ravens Found establishes. The beginning of The Land the Ravens Found describes "A WILD SEA [sic], even in the middle of summer, choppy waves running every way at once, clear sign to seamen of violent currents, treacherous and difficult" (11). Given that ships were the Vikings' usual mode of transport, the sea is therefore a war zone. The novel's deployment of the adjective "difficult" to describe both the sea and Aud's search for land therefore links the latter event to war but then undermines that connection in relating her comparative lack of capacity to deal with Iceland's terrain, thereby subverting the implications of Landnámabók's employment of the verb nema in describing the matriarch's land-taking.

Indeed, the composition of Aud's comb and the trajectory of her response to its loss affirm her anti-war mentality. Aud's comb consists of "gold and ivory" - that is, it is made of ivory and decorated with gold. Before and during the Settlement Period, Vikings perceived Ireland, which unlike medieval Scandinavia produced combs made of ivory, ${ }^{74}$ as a (plunderable) source of both gold and silver. ${ }^{75}$ Given that both Landnámabók and The Land the Ravens Found contextualize Aud's husband, Anlaf, as Dublin's conqueror and ruler (although when the novel begins, he is long since dead), the matriarch's possession of her comb makes her complicit not only in war but in territorial oppression. On a symbolic level, Aud's response to the loss of her comb represents her relinquishment of what for lack of a better term I will call "imperial authority."

It is no coincidence, then, that The Land the Ravens Found concludes its version of this episode by reaffirming Aud's aversion to conflict through her conformity to conventional gender roles. When Aud's grandson, Anlaf Feilan, comments that the loss of her comb may be interpreted as "a sacrifice for the new land" (148), his grandmother "[tells] him to mind his own business" (148) while "twisting her hair which was very long still, for all it was grey, round a stick, and [pulls] the hood of her cloak well over it" (148). Again, married women customarily wrapped their hair into a bun with a veil over it. ${ }^{76}$ Thus, Aud's insistence upon maintaining this 
propriety even in the absence of her comb constitutes her commitment to civilizing norms. But Aud's response to the remarks of her young grandson constitutes a rebuke to his continuing support of the paganism that defines itself through its violence, which is specifically that of aggressive warfare. While expressing his thoughts aloud, Aud's grandson is "thinking of his arm ring" (148) which he had earlier thrown into the sea as a sacrifice so that his grandmother's ship might land safely in Iceland at the very moment when it was apparently about to be wrecked. That "arm ring," which had been "his father's last present to him" (118), is a "thick gold bracelet" (118). Notably, Thorstan's first appearance in The Land the Ravens Found revolves around his return from a raid, the spoils of which explicitly include jewellery and hair ornaments for his daughters, Anlaf's sisters. In this light, the novel implicitly contextualizes Anlaf's "arm ring" as booty from that same attack. As such, it is an object of plunder and therefore an emblem of viking aggression.

That Aud has already defined the valley below the cliff on which she eats as "her boundary" (146) notwithstanding, The Land the Ravens Found, like Landnámabók, relates her landnám as the follow-up to her experience in Combness:

They camped that night and went on the next day along the sides of the great sea loch that was called Hwamm Fjord. Aud made up her mind what land she would take. She did not want more than she could look after, but only part of any holding could be cultivated ... In the end she made a biggish claim because she wanted to have plenty of land to give away to her shipmates. It would be better, having regard to the rest of the settlers, if she should be the one to make the claim and uphold it before the Thing, the Parliament, when it met, so that everything should be within the law. (148)

"Eyrbyggja saga," Zoe Borovsky says, "states that women lost their rights as plaintiffs after a legal disaster circa 992." light, Aud's intention of establishing the legitimacy of her land 
claim by declaring it at court has no bearing on her identification with traditional Norse roles of either gender, although it is worth pointing out that Iceland's first law code, Grágás ("Grey Goose" [1117-18]), more or less prohibited women from participating in the Ping ${ }^{78}$ and doubtless reflects long-standing social and legal conventions that predate its own existence in written form.

Nevertheless, Aud's settlement in The Land the Ravens Found substantiates her status as a woman overall. First, Aud's justification for "[making] a biggish claim" indicates that she has both a sense of camaraderie and respect for the rules of the community that she has joined, two qualities that distinguish her as a civilized individual and thus associate her with society. Second, Aud's landnám in The Land the Ravens Found is precisely what it is not in Landnámabók. Hauksbók's description of Thor-gerd's settlement, as I earlier pointed out, illustrates by way of contrast how Aud claims land in that text not as a woman but rather as a man. As Thor-gerd's actions imply, a woman may legally claim as much land as she can encircle with a two-year-old heifer in tow between daybreak and dusk which in the spring constitutes an approximately twelve-hour span. That measure arguably defines Aud's landnám in The Land the Ravens Found which, aside from the land that she claims temporarily for the purpose of giving it away, seems to fulfill her initial desire to claim no more land than she can manage. In the 1955 novel, then, the dimensions of Aud's landnám coincide with the terms by which a "woman settler" (landnámskona) may take land.

\section{Conclusion}

Near the end of its account of her, Landnámabók unequivocably praises Aud as "a worshipful lady" (84/ vegs-kona mikil). ${ }^{79}$ The literal translation of vegs-kona mikil, "great woman of glory," points to its own equivocality in referring to Aud as such in that it is her accomplishments as depicted in Landnámabók $k^{80}$ that have earned her such regard, deeds that underscore how she embodies and performs the role of a "best-born settler" and that thereby identify her not only with masculinity but with war. Vegs-kona mikil also, I would argue, aptly describes Mitchison despite the fact that her depiction of Aud as the embodiment of pacifism in The 
Land the Ravens Found paradoxically identifies the latter with traditional womanhood, conventionalizing a medieval figure whom Landnámabók esteems even as it implicitly associates her with war. For when all is said and done, instituting peace is not merely preferable to perpetuating war but one of the highest goals that humankind can and should pursue. In this light, The Land the Ravens Found, which years after Mitchison's demise still advocates on her behalf for the establishment of a pacifist community, defines her as an enduring force of progression-one not unlike her protagonist, as the novel's final lines imply:

"She built Safe Farer," said Thorgerd[,] "and brought us here. She made everything different."

"And better," said Anlaf Feilan. (190)

\section{Notes}

${ }^{1}$ Julian Meldon D'Arcy, Scottish Skalds and Sagamen: Old Norse

Influence on Modern Scottish Literature (East Linton: Tuckwell, 1996), 155.

${ }^{2}$ Naomi Mitchison, Small Talk. . Memories of an Edwardian Childhood in As It Was: An Autobiography 1897-1918 (Glasgow: Richard Drew Publishing 1988), 52. Mitchison does not specify which sagas she read at this time.

${ }^{3}$ Naomi Mitchison, Mucking Around: Five Continents Over Fifty Years (London: Gollancz, 1981), 44. Mitchison states in this work that she was in Norway "in the late Twenties"; she specifies that she was in Oslo (and also Stockholm) in the spring of 1929 in You May Well Ask: A Memoir, 1920-1940 (London: Gollancz, 1979), 166.

${ }^{4}$ Mitchison, You May Well Ask, 166.

${ }^{5}$ D'Arcy, Scottish Skalds and Sagamen, 163.

${ }^{6}$ Naomi Mitchison, Bibliography for The Swan's Road (London: The Naldrett Press, Ltd., 1954), 151.

${ }^{7}$ Mitchison, Bibliography for The Swan's Road, 151.

${ }^{8}$ Mitchison, Bibliography for The Swan's Road, 151.

${ }^{9}$ D'Arcy, Scottish Skalds and Sagamen, 163.

${ }^{10}$ Although in her view Landnámabók cannot wholly be explained as a narrative justification of land ownership on the part of prominent 
Icelanders between 1100 and 1199 given that many settlers mentioned in the text did not have illustrious descendants, Margaret Clunies Ross admits that "we cannot escape the hermeneutic circle in which early settlers are represented by their descendants as invoking supernatural revelations of an authority that was significant, as invested in the pioneers, to the extent that their descendants were successful in the colony" ("LandTaking and Text-Making in Medieval Iceland" in Text and Territory: Geographical Imagination in the European Middle Ages, eds. Sylvia Tomasch and Sealy Gilles [Philadelphia: University of Pennsylvania Press, 1998], 161). Adolf Friðriksson and Orri Vésteinsson largely concur in arguing that producing narratives of the nation's prosperous familial dynasties was not inimical to that which they perceive as the impetus behind the composition of Landnámabók ("Creating a Past: A Historiography of the Settlement of Iceland" in Contact, Continuity and Collapse: The Norse Colonization of the North Atlantic, ed. James H. Barrett [Turnhout, Belgium: Brepols Publishers, 2003], 139-161).

${ }^{11}$ For the sake of readability, I will, for the most part, cite English translations before providing the corresponding Norse text; with respect to longer passages in the main text of this paper, the corresponding original text will be quoted in the endnote that respectively will accompany each translation. Aud's appearance in five Old Icelandic texts besides Landnámabók-Ari Porgilsson's Íslendingabók (The Book of Icelanders); Brennu-Njáls saga (The Saga of Burnt Njal); Eyrbyggja saga (The Saga of the Dwellers of Eyrr); Eiriks saga rauða (The Saga of Erik the Red); and Laxdcela saga (The Saga of the People of Laxardal) — testifies to her significance within Norse culture as the common ancestor of those living in western Iceland, although only the latter text also provides a full account of Aud's land-taking (which deviates somewhat from Landnámabók's). Laxdcela saga is the only other text besides Landnámabók that imbues Aud with both narrative and thematic significance; from the perspective of character development, the saga provides a richer account of her settlement than Landnámabók does. Although an examination of Aud's presence in this saga would be germane to my discussion here, I have elected, in part for reasons having to do with constraints of time and space and in part because Mitchison herself clearly positions The Land the Ravens Found in relation to Landnámabók, not to analyze Laxdoela saga's depiction of the settler in this essay. Another narrative in which Aud also features more prominently is "Gullbra og Skeggi í Hvammi" ("Goldbrow and Skeggi at Hvamm"). 
That the first extant allusion to "Gullbra og Skeggi í Hvammi" dates to 1690 does not rule out the possibility that it first surfaced during the medieval period, but there is no conclusive evidence indicating that the narrative existed before 1450. This story, which contextualizes Aud as a Christian foil for the (pagan) witch Gullbra, appears to take place long after the widow has settled in Iceland and does not seem to engage the themes that are the focus of this essay.

${ }^{12}$ Naomi Mitchison, Postscript to The Land the Ravens Found (London: Collins, 1955), 191.

${ }^{13}$ Mitchison, You May Well Ask, 166.

${ }^{14}$ Landnama-book, or the Book of Settlements in Origines Islandicae: A Collection of the More Important Sagas and Other Native Writings

Relating to the Settlement and Early History of Iceland, Vol. 1, eds. and trans. Gudbrand Vigfusson and F. York Powell (London: Oxford at the Clarendon Press, 1905), Hauksbók V.17.2. Vigfusson and Powell's translation of Landnámabók is the source of all quotations in English from this work; this edition is also the source of all quotations in Norse from Landnámabók. All subsequent citations for translations in English from this text will provide in-text page numbers only; the corresponding Norse text quoted in the endnote that will respectively accompany each translation will list the book, chapter and subsection in which it appears. ${ }^{15}$ While Margaret Clunies Ross argues that Aud's "landnám" as it is depicted in Landnámabók reinscribes contemporary perceptions of landtaking as a "male activity" ("Land-Taking and Text-Making", 160) in its distinctiveness from the settlements of men that are described in the same text, a uniqueness that paradoxically renders it an exemplar of female settlement, Preben Meulengracht Sørensen (The Unmanly Man: Concepts of Sexual Defamation in Early Northern Society, trans. Joan Turville-Petre [Odense, Denmark: Odense University Press, 1983]) and Carol Clover ("Regardless of Sex: Men, Women, and Power in Early Northern Europe." Speculum 68 (1993): 363-387) assert that Aud performs as a man.

${ }^{16}$ Although Mitchison made her reputation as a writer of historical fiction, the endurance of that status has not matched that of her interest in composing it, a phenomenon that probably reflects the fact that the writer did not confine herself to any one genre (Lesley A. Hall, Naomi Mitchison: A Profile of Her Life and Work [Seattle: Aqueduct Press, 2007], 3; Moira Burgess, "Naomi Mitchison" in Dictionary of Literary Biography, Vol. 319, ed. Cheryl Alexander Malcolm [Farmington Hills, MI: Thomson/Gale, 2006], 237). Mitchison was also a poet, playwright, 
journalist and memoirist; before the Second World War, she debuted as a writer of contemporary fiction (to which audiences did not respond as favorably as they had to her earlier works of historical prose; folklore, history, realism and fantasy each informed her literary output during and after (for a good fifteen or so years) the Second World War (Burgess, "Naomi Mitchison," 237). In the early 1960s, Mitchison added herself to the ranks of science fiction writers (Hall, Naomi Mitchison, 6).

${ }^{17}$ Moira Burgess observes that The Conquered, Mitchison's first novel which was published in 1923, takes place "in Roman-occupied Gaul in the first century B.C.," that "[t]he epigraphs to each chapter indicate the relevance of the book to the troubled situation prevailing in Ireland at the time it was written" and that "such comparison of past with present is a recurrent feature of Mitchison's writing" ("Naomi Mitchison," 238).

${ }^{18}$ D'Arcy, Scottish Skalds and Sagamen, 173.

${ }^{19}$ Jill Benton, Naomi Mitchison: A Biography (London: Pandora, 1990), 140. Mitchison's optimism about "racial relations" (D'Arcy, Scottish Skalds and Sagamen, 173) in The Land the Ravens Found informed her concern about the relationship between the Cold War adversaries thirty years later. In her 1984 foreword to Among You Taking Notes (ed. Dorothy Sheridan [London: Victor Gollancz Ltd., 1985]), the diary that she maintained during the Second World War as part of the MassObservation project that two of her friends, Tom Harrisson and Charles Madge, commenced in 1937 along with another colleague, Humphrey Jennings, with the goal of gaining insight into the daily routines of members of the British public, Mitchison states that her journal is "full of hope for a new kind of world, for something different, happier, more honest, for a new relationship between people who had been cut off from one another by money, power and class structure" and that it is her conviction that "these kind of hopes were common enough in the UK [the U.S.'s Cold War ally] and probably to some extent in all the countries involved in the war, above all in the Soviet Union" (12-13).

${ }^{20}$ D'Arcy, Scottish Skalds and Sagamen, 170.

${ }^{21}$ One of Mitchison's biographers, Jenni Calder (The Nine Lives of Naomi Mitchison [London: Virago, 1997]), quotes from and discusses this essay but in linking it to The Land the Ravens Found does not mention the AWPA at all, let alone as a catalyst for either work.

${ }^{22}$ Naomi Mitchison, "The Writer and the Child," The New Statesman and Nation, 12 February 1955, 203.

${ }^{23}$ Mitchison, "Writer and the Child," 203-204. 
${ }^{24}$ I am echoing Jill Benton's assertion that Mitchison's participation in the AWPA resulted in the composition of The Land the Ravens Found (Naomi Mitchison, 142). Critics have not uniformly defined The Land the Ravens Found as children's literature, and Calder herself has asserted that stylistically and substantively, there is no real difference between Mitchison's putative works for adults and books for children (Nine Lives, 216).

${ }^{25}$ Mitchison, "Writer and the Child," 203.

${ }^{26}$ Mitchison's oldest child, Geoff, had contracted meningitis and had died of it in 1927; her sixth child, Valentine, was born in 1930; Mitchison's last child, a daughter, would die soon after birth in 1940 .

27 The marriage ended with the death of her husband, Dick, in February of 1970 .

${ }^{28}$ Naomi Mitchison, "Comments on Birth Control" (London: Faber and Faber, 1930), quoted in Calder (Nine Lives, 94).

${ }^{29}$ Calder, Nine Lives, 94.

${ }^{30}$ Calder, Nine Lives, 95.

${ }^{31}$ Mitchison, "Comments on Birth Control" quoted in Calder (Nine Lives, 95).

${ }^{32}$ Orthographically speaking, from this point on, I will follow Vigfusson and Powell when referring to names of people in Landnámabók and Mitchison when referring to characters in The Land the Ravens Found. 33 "Efter um váret fóro pau Auðr í Breiða-fiaorð inn í landaleitan. . ." (Hauksbók II.14.7). In Hauksbók, the fact that Auðr's entourage accompanies her is implicit.

34 ، . . . pau aoto daogorð fyr sunnan Breiða-fiaorð par sem nú heiter Daogorðar-nes. Síðan fóro pau inn um Eyja-sund. Pau lendo við nes pat es Auðr tapaðe kambe sínom—-pat kallaðe hon Kambs-nes" (Hauksbók II. 14.7). It should be noted that Hauksbók deploys "sunnan" ("south") for that which in Sturlubók, the earlier of the two complete compilations of Landnámabók still in existence, (correctly) reads "norðan" ("north"). Vigfusson and Powell's own translation accordingly follows Sturlubók here. It should also be noted that any emendations in the English translations of passages from Landnámabók that I quote at length are those of the translators, Gudbrand Vigfusson and F. York Powell. Emendations in English translations of brief phrases or lines from Landnámabók that I have embedded within my own sentences are mine.

${ }^{35}$ Ross, "Land-Taking and Text-Making", 176.

${ }^{36}$ Ross, "Land-Taking and Text-Making", 176.

${ }^{37}$ Ross, "Land-Taking and Text-Making", 176. 
${ }^{38}$ It isn't quite clear as to whom "they" refers. I would argue that "they" likely alludes to his retinue.

39 "Skalla-Grímr kom par at lande es nú heiter Knarrar-nes á Mýrom. Sídan kannaðe hann landet, ok vas par mýr-lende miket, ok skógar víðer langt á miðle fiallz ok fiaoro. En es peir fóro inn með firðenom, kómo beir á nes pat es peir fundo alfter-pat kaolloðo peir Alfta-nes. .." (Hauksbók I.8.1).

${ }^{40}$ See Note 38 .

41 “. . . kómo peir at ao peirre es peir kaolloðo CExar-ao, pví at peir týndo par í œxe sínne. Peir aotto dvaol under fiallz-múla peim es peir kaolloðo Reyðar-múla: par laogo peim efter á-reyðar pær es peir tóko or aonne" (Hauksbók V.14.2). Hauksbók includes a slightly different second version of this account. Hauksbók claims that this alternative passage is from Sturlubók, but the latter does not contain it: "[Double text. 'But when they had gone a short distance they came to a frozen river, and cut an ice-hole in it, and their axe fell in, whence they called it Ax-water. This water was afterwards led into the All-men's-rift, and now it runs down along the Ting-wall [Moot-field]. Then they went to where it is now called Troutmull; there they lost their [catch of] trout, whence they called it Troutmull.]" " (228)/ "[Sturl. S.7.12: 'En es peir vóro paðan skamt farner, pá kómo peir á ár-ís, ok hioggo par á vaok, ok felldo í œxe sína, ok kaolloðo hána af pví Exar-ao.-Sú ao vas síðan veitt í Almanna-giao, ok fellr nú efter Ping-velle.-—á fóro peir par til es nú es kallaðr Reyðarmúle: par urðo peim efter reyðar pær es peir fóro með, —ok kaolloðo par af pví Reyðar-múla.]' " (Hauksbók V.14.2).

42 "Peir kómo í fiaorð pann es peir fundo hrúta tvá-peir kaolloðo par Hrúta-fiaorð. .." (Hauksbók III.5.2).

43 "Pole" is the English translation of "stöng."

${ }^{44}$ Peter G. Foote and David M. Wilson, The Viking Achievement (New York and Washington: Praeger Publishers, 1970), 174.

45 "I refer the stem syllable hor- to the root *hazwa-> ON hor-r, OHG haro, 'flax.' This word is connected with the IE root *kes. . ' 'to comb' and evidently originally signified 'that which was combed' " (Albert Morey Sturtevant, "Certain Old Norse Suffixes." Modern Philology 26 (1928): 155).

${ }^{46}$ Michael P. Speidel, Ancient Germanic Warriors: Warrior Styles from Trajan's Column to Icelandic Sagas (London and New York: Routledge, 2004), 180. 
${ }^{47}$ Speidel, Ancient Germanic Warriors, 180. Speidel's own sources for this information are Paul the Deacon's Historia Longobardorum and Gregory of Tours' History.

${ }^{48}$ Speidel, Ancient Germanic Warriors, 180. Speidel's sources for this information are Snorri Sturlusson's Haralds saga Hárfagra, Höfler's Runenstein and Rives' Tacitus.

${ }^{49}$ Generally speaking, the family sagas cite the tyranny of Haraldr Hárfagri ("Fair-hair"), who subjugated the territories comprised by Norway to his rule between $870-930$, as the reason for emigration from Norway to Iceland.

${ }^{50}$ Insofar as we might perceive the disarray of Aud's hair as a performance of masculinity, it reinforces Preben Meulengracht Sørensen's assertion, with which Carol Clover concurs ("Regardless of Sex", 366), that the matriarch "[acts] as a man because the men who should have acted on her behalf were dead" (Unmanly Man, 22) and relates her to the Norse "shield-maiden," a definition that applies "to any and all women who take up the sword or associate themselves with warfare or merely behave in unfeminine ways, however briefly and for whatever reason" (Carol Clover, "Maiden Warriors and Other Sons." The Journal of English and Germanic Philology 85.1 (1986): 36).

${ }^{51}$ Richard Cleasby, Gudbrand Vigfusson and William A. Craigie, An Icelandic-English Dictionary, 2nd ed. (London: Oxford University Press, 1969), s.v. "nema."

52 Icelandic-English Dictionary, s.v. "nema."

53 "Auðr nam aoll Dala-laond í innan-verðom firðenom frá Daogorðar-ao til Skraumo-hlaups-ár. Hon bió í Hvamme við Aurriða-ár-ós-pat heita Auðar-tofter" (Hauksbók II. 14.8).

${ }^{54}$ These variations include basic constructions such as "[h]ann nam land. . ." ("he took land. ..") and "[s]iðan nam hann [Y]. .." ("after that took he [Y]. ..") where the antecedent of "[h]ann" is the name of the settler, and compound sentences in which the subject noun or pronoun denoting the settler is not adjacent to the third person preterite singular of the infinitive "nema" ("to take") such as the following example from Landnámabók's description of the settlement of Helgi Beolan in Hauksbók I.5.1: "Hann vas með Ingolfe enn fyrsta vettr, ok nam með hans ráðe Kiarlar-nes allt miðle Mógils-ár ok Mýdalsár . .." (He was with Ing-wolf the first winter, and took at his rede all Keel-ness between Mo-gils-river and Midge-dalewater" [26]).

${ }^{55}$ Hauksbók identifies a total of thirty-nine of them.

${ }^{56}$ See Hauksbók IV.4.1. 
${ }^{57}$ Icelandic-English Dictionary, s.v. "nema."

${ }^{58}$ Icelandic-English Dictionary, s.v. "nema."

59 According to Sturlubók, Thor-gerd claims land jointly with her sons by As-beorn (see S 316).

${ }^{60}$ Grágás, Iceland's first law code, says nothing about the land claims of women (Laws of Early Iceland: Grágás I, trans. Andrew Dennis, Peter Foote, Richard Perkins [Winnipeg, Canada: University of Manitoba Press, 1980] and Laws of Early Iceland: Grágás II, trans. Andrew Dennis, Peter Foote, Richard Perkins [Winnipeg, Canada: University of Manitoba Press, 2000]). However, this omission makes historical sense given that Ari porgilsson tells us in Íslendingabók (The Book of Icelanders), the oldest account of medieval Icelandic society still in existence, that the final landnám occurred in 930, and Grágás did not come into existence until 1117 -i.e., such a law would have been obsolete by the early twelfth century.

61 " 2 . En pat vas mælt, at kona skylde eige víðara nema land an leiða mætte kvígo tvæ-vetra vár-langan dag sól-setra miðle, half stalit naut ok haft vel. Dví leidde bórgerdr kvígo sína undan Tofta-felle skamt frá Kví-ao suðr, ok í Kiðjá-leit hiá Iaokuls-felle fyr vestan.

“3. Pórgerðr nam par land um allt Ingolfs-(haofðá)-hverfe, á miðle Kví-ár ok Iaokuls-ár; ok bió at Sand-felle" (Hauksbók IV.15.2-3).

${ }^{62}$ Naomi Mitchison, The Swan's Road (London, The Naldrett Press, Ltd., 1954), 14.

${ }^{63}$ D'Arcy, Scottish Skalds and Sagamen, 163.

${ }^{64}$ Benton, Naomi Mitchison, 117.

${ }^{65}$ Benton, Naomi Mitchison, 119-21.

${ }^{66}$ Benton, Naomi Mitchison, 121-123.

${ }^{67}$ Naomi Mitchison, The Land the Ravens Found (London: Collins, 1955), 145-46. This volume is the source of all quotations from this work; all subsequent citations from this text will provide in-text page numbers only. ${ }^{68}$ See Note 33.

${ }^{69}$ Trausti Valsson notes that while the citification of modern Iceland has mitigated its vulnerability to the dangers posed by some of its geographical and climatic features, "[i]n earlier times many aspects of weather were. . . a great threat to people and their well-being, such as cold spells and heavy winds" (Planning in Iceland: From the Settlement to Present Times [Reykjavík: University of Iceland Press, 2003], 42). Indeed, as a 2001 examination of Iceland's geographical conditions in and around Reykjavík during the Settlement Period has revealed, the land claim of Iceland's first permanent resident, Ingólfr, was, with respect to its 
potential for agricultural development, optimally situated (Trausti Valsson, Planning in Iceland, 51). Notably, two of the elements in favor of the land that Ingólfr acquired were its "[s]heltered areas" and its proximity to water while "[s]teep terrain" was one of several "[n] egative or excluding factors" (Trausti Valsson, Planning in Iceland, 51).

${ }^{70}$ Jenny Jochens, Women in Old Norse Society (Ithaca, NY and London: Cornell University Press, 1995), 120; 129.

${ }^{71}$ Jochens, Women in Old Norse Society, 120.

72 Jochens, Women in Old Norse Society, 124.

${ }^{73}$ Jochens, Women in Old Norse Society, 123.

${ }^{74}$ Nancy Edwards, "The Archaeology of Early Medieval Ireland, c.4001169: Settlement and Economy" in A New History of Ireland I:

Prehistoric and Early Ireland, ed. Dáibhí Ó Cróinín (Oxford and New York: Oxford University Press, 2008): 281.

${ }^{75}$ Patrick F. Wallace, "The Archaeology of Ireland's Viking-Age Towns" in New History of Ireland I: 836.

${ }^{76}$ Foote and Wilson, Viking Achievement, 174.

77 Zoe Borovsky, "Never in Public: Women and Performance in Old Norse Literature." The Journal of American Folklore 112 (1999):12.

78 "The most important public event in medieval Iceland was the annual meeting of the Althing ... where Icelandic law obtained. . . The performance roles at the Althing-lawspeakers, chieftains, judges, plaintiffs, and witnesses-were filled by males. . . A woman could attend $\ldots$ as a member of the general public, but she ... had to 'sit on the outside of the benches' ... However, the Icelandic law codes were inconsistent with regard to the kinds of cases women could plead, which suggests a legal loophole. A widow or an unmarried girl of 20 could take charge of her own lawsuit if it was about an assault or a minor wound (Grágás 1980: 158). One version of Grágás, "Konungsbók," states that a woman in a similar position ... could prosecute a killing case (Grágás 1980: 157), but another version, "Staðarhólsbók," contradicts this and stipulates that in no instance could a woman be a plaintiff. . ." (Borovsky, "Never in Public," 12). The exceptions to the rule that Borovsky describes do not apply to Aud because her reason to appear before the Ping has nothing to do with seeking compensation for physical harm.

${ }^{79}$ Hauksbók II.15.15.

${ }^{80}$ Laxdcela saga's account of Auðr's land-taking also relates most of these acts. 